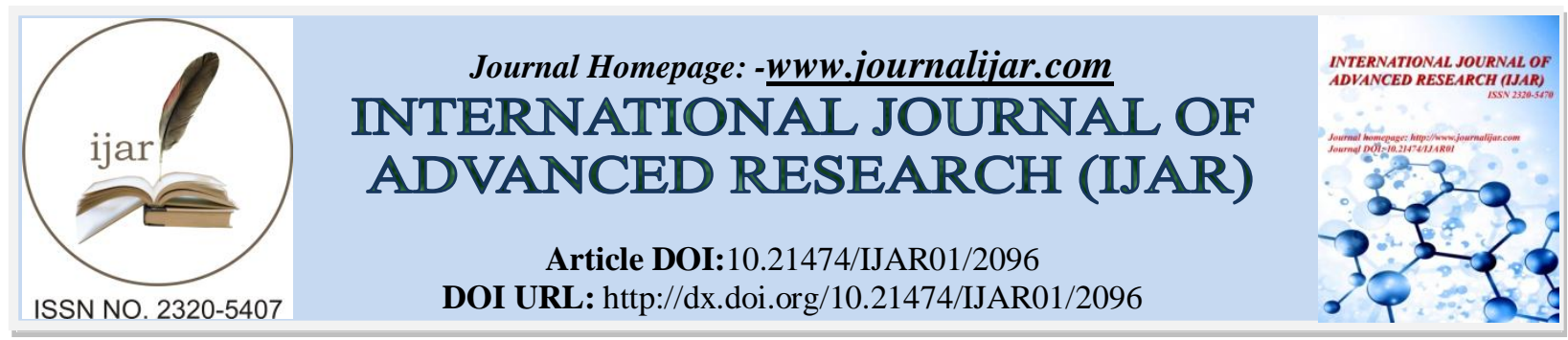

RESEARCH ARTICLE

\title{
INFLUENCE OF LATEX RUBBER ON MECHANICAL PERFORMANCE FLEXIBLE BRICKS.
}

"P.S.O. Jolissaint, O.M. Boffoue, A. M. Serifou, C.K. Kouadio, H.C. Kouakou and E. Emeruwa. University Felix HouphouëtBoigny, Geomaterial laboratory, ufr of earth sciences and mineral resources, 22 B.P. 582 Abidjan 22, Abidjan, Ivory Coast.

\section{Manuscript Info}

Manuscript History

Received: 24 September 2016

Final Accepted: 26 October 2016

Published: November 2016

Key words:-

Latex rubber; Flexible facing brick;

Flexibility test; Lengthening test.

\begin{abstract}
The latex rubber is mixed with sand for making flexible facing bricks. These bricks were submitted to tests (flexibility test, lengthening test and usury resistance) and the microstructure studies to determine their mechanical performances and understand the effects using the latex rubber in the bricks. Bricks flexibility increases on the upper side when the latex content grows up to $16 \%$. It passes through an optimum at 16 $\%$ of latex before decreasing. On the other hand underside flexibility of the bricks increases with increasing latex content. Usury tends to be canceled with $18 \%$ of latex. Strengthening the sand with the latex also shows that bricks have the ability to grow until $12 \%$ and can resist to a maximum load of $65 \mathrm{~N}$. The latex can link and coat progressively the sand particles. Microscopic observations of the bricks shows a variation of the structure of composites according to the latex ratio. It gives a good coating of sand particles with latex from $16 \%$ with more related interfaces between 10 and $15 \%$ of latex.
\end{abstract}

Copy Right, IJAR, 2016,. All rights reserved.

\section{Introduction:}

The construction industry employs a wide range of products: bricks, concrete, tiles and facing bricks. Facing bricks are typically made of: ceramics, clay stabilized, laterite and small thicknesses. They are used for interior and exterior coating of buildings. The bricks are fired or stabilized with binder such as Portland cement. The use of facing bricks in the building as walls and especially the rounded structures is a problem that the masons should solve because these bricks are rigid. Therefore they are used to cut them with risk the destruction of the product. In addition, this model requires for Mason lot of efforts and a waste of time. In addition the result is bad in general after laying these bricks on the rounded surfaces. Thus in order to resolve these problems of inadequacy of these rigid bricks on rounded surfaces, this study was planned in order to develop flexible facing bricks made of local raw materials: sand and latex rubber. These bricks will be submit to mechanical characterization tests to determine their performances.

\section{Materials and methods: \\ Raw materials:}

The raw materials used for the realization of this work are the sand and latex rubber. The sand from a quarry located at Port-Bouet (Abidjan). For this study this sand is sieved and particles larger than 1 $\mathrm{mm}$ are removed to give bricks a fine texture. Granulometric and mineralogical analyses indicate that it composed of $35 \%$ of fine sand whose grain size is between 0.08 and $0.315 \mathrm{~mm}$ and $65 \%$ of medium sand whose grain size is between 0.315 and $1 \mathrm{~mm}$. The $\mathrm{Cu}$ Hazen uniformity coefficient is 2.5 , our sand has a narrow particle size 
distribution. Mineralogical analysis was performed by X-ray diffraction It shows that the sand is mainly composed of quartz ( $\mathrm{SiO} 2)$.

The latex rubber is used as a binder. It is a natural binder. The rubber latex, used to make flexible facing bricks, comes from a private plantation near Dabou (Ivory Coast). It is used in liquid form for the realization of bricks. The rheological behavior of the rubber latex shows that when the mixing time is long, the liquid phase is denser and its viscosity increases. The latex separates itself into two phases, namely a gaseous phase and a liquid phase that we also observe in ultracentrifugation of the rubber latex (Chrestin, 1984).

\section{Elaboration of bricks}

The figure 1 presents the brick making process.

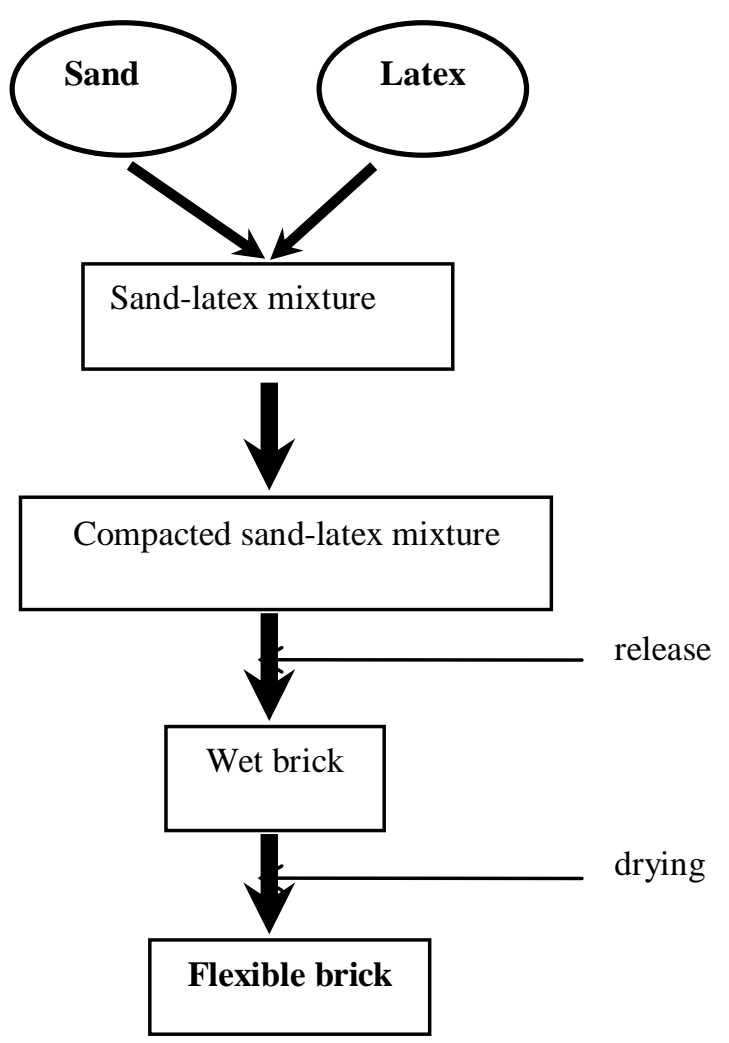

Figure 1: brick making process

Drying takes 7 days to allow the coagulation of rubber latex. After drying, bricks were subjected to mechanical characterization tests.

\section{Characterization bricks:}

Flexibility test:

The elaborate bricks have two sides that can be used as outside (apparent) on the future building. They correspond according to the compacting mode to the upper or under face of the brick (figure 2). Brick flexibility on both sides; with latex contents, varying between 10 and $22 \%$; was measured. 


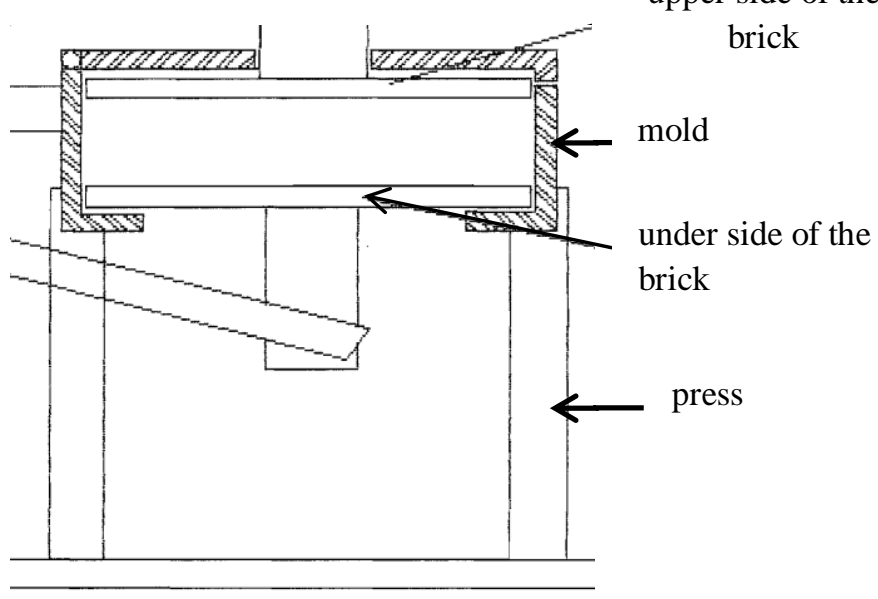

Figure 2:Diagram showing the upper and under side of the bricks

The purpose of this test is to know bending angle limit when the specimen is folded. This curvature limit angle called angle flexibility. For measuring angles flexibility, we set the brick on the sample holder with screws, a rotational movement of the crank allows folding until the appearance of first cracks. This flexibility test device has been developed by Jolissaint (2015). On recognition of the presence of cracks, flexibility limit is observed. The bending angle is read on a protactor. It is provided in degrees $\left({ }^{\circ}\right)$.

\section{Lengthening test:}

This test consists in submitting the brick to load and measuring lengthening relative of the brick. The brick is attached to a support, and submitted to different loads. When the brick lengthens and upon the finding of the appearance of cracks, we read the elongation on the graph paper. The distortion is calculated by applying the following formula:

$$
\varepsilon(\%)=\frac{\mathrm{L}-\mathrm{L}_{0}}{\mathrm{~L}_{0}} \times 100
$$

Where,

$\varepsilon$ : Distortion in \%

$\mathrm{L}$ : length to the appearance of cracks, in $\mathrm{mm}$

$\mathrm{L}_{0}$ : initial length, in $\mathrm{mm}$

We also measure the load that causes the appearance of cracks on the brick. This load is provided in Newtons $(\mathrm{N})$.

\section{Usury resistance:}

The wear test characterizes the abrasion resistance of the faces of bricks. The procedure used in this test consisted in immersing bricks in to water for 24 hours and then drying them in the sun until constant weight. Before each test, dimensions and weight of samples are measured. Each face is subjected to a cycle of 25 brushings. A brushing cycle corresponds to a round trip of the brush along the entire length of the brick while ensuring that the over half of the brush remains permanently in contact with the surface thereof. This usury resistance device has been developed by Kouakou (2005). At the end of brushing, the surfaces are thoroughly cleaned to eliminate items that were detached and the weight $\left(\mathrm{M}_{\mathrm{f}}\right)$ is determined; a mass $\mathrm{M}_{\mathrm{f}}$ is obtained. 
Wear is given by the formula:

$$
\mu=\frac{M_{i}-M_{f}}{S_{f}}
$$

Where,

$\mu$ wear is provided in $\mathrm{g} / \mathrm{cm}^{2}$,

$\mathrm{M}_{\mathrm{i}}$ is the mass (g) of the dry sample before brushing,

$\mathrm{M}_{\mathrm{f}}$ is the mass (g) of the sample after brushing,

$\mathrm{S}_{\mathrm{f}}$ is the brushed surface $\left(\mathrm{cm}^{2}\right)$.

\section{Results and discussion:}

Latex effect on the flexibility of bricks:

The figure 3 shows respectively the results of measured bending angles of the upper side and the underside of the bricks according to the latex content.

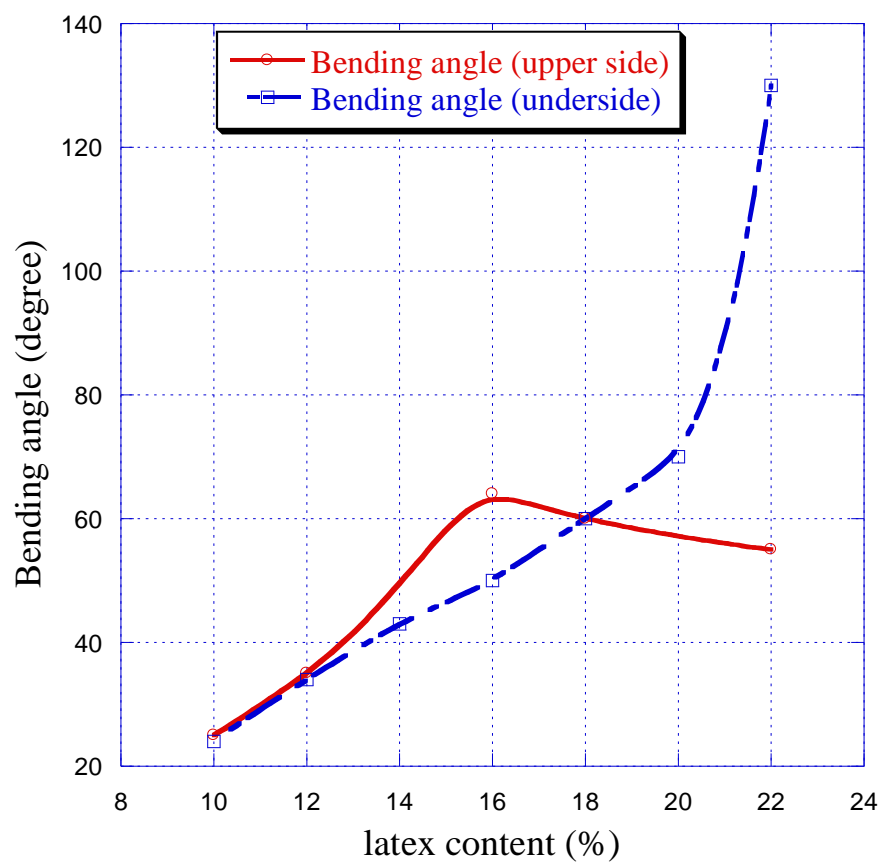

Figure 3: Change in flexibility depending on the latex content for different faces bricks

Bending angle varies with the latex content in the first time. It increases with the increase of the latex content for the both sides. For upper side the flexibility decreases when latex content is more than $16 \%$, however, the bending angle still to increase on the underside. This increase in the bending angle on the under side is increasing sharply beyond $20 \%$ because the slope of the curve changes. This is due to the unidirectional compaction. The behavior of the upper face over $16 \%$ of latex is due to the incremental increase of the density gradient between the two faces.

From $16 \%$ of latex, the under face is more dense while the upper face is less dense, the latex tends to migrate by gravity to the bottom. Internal stresses appear and the fine layers of latex tear resulting in a low flexibility. In addition, between 18 and $22 \%$ of latex, the values of the bending angle on the lower side are higher than those obtained on the upper face of the brick. This could be justified by structure of the latex in the mixture.

The electron microscopy observations of the bricks are shown in figure 4.

They show the amount of rubber on each side of the bricks. It is observed that on the upper side, the rubber is only confined between particles of sand while on the underside it covers the surface of the particles. The amount of rubber is therefore higher on the underside than on the upper face. It's the reason why over $18 \%$, angle under face is 
greater than that of the upper face. In a unidirectional compression, it appears a density gradient. For the study the underside is more dense, so its flexibility is greater. Indeed by gravity after compaction, excess latex accumulates on the underside. To this is added, plasticity of the latex, the more latex over the face is flexible.
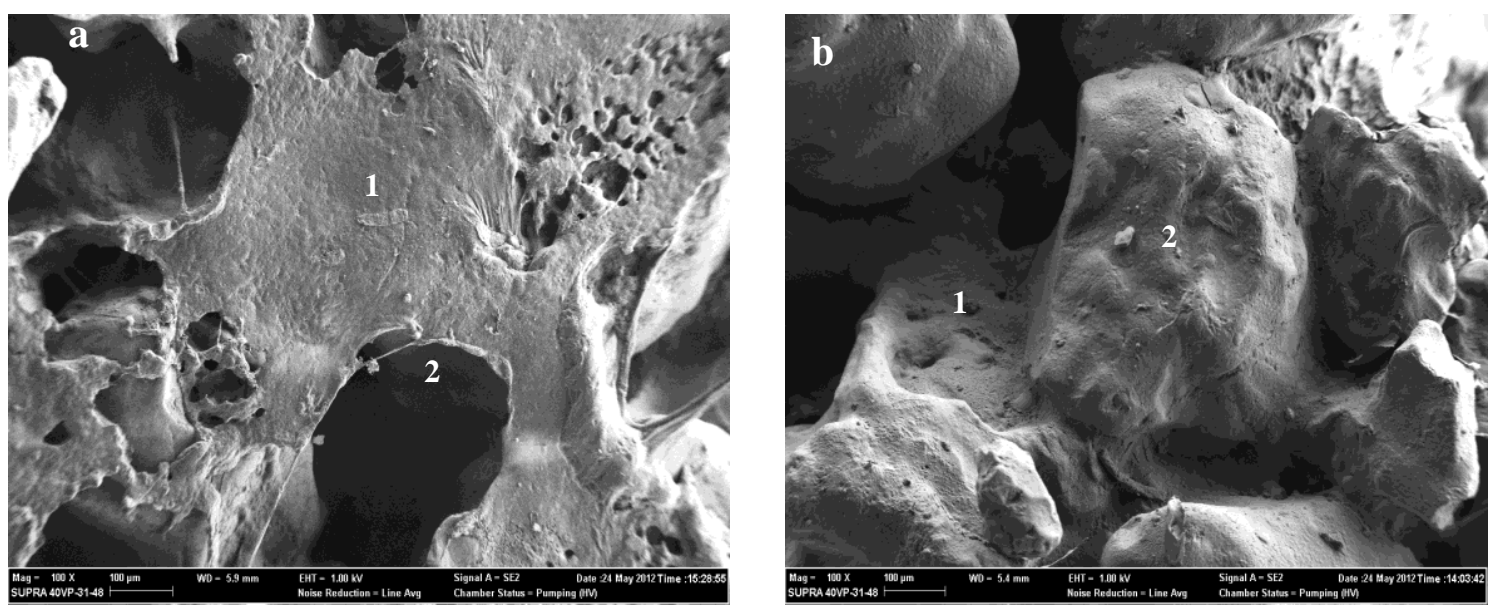

a) Under sideb) Upper side

\section{Latex 2. Sand particle}

Figure 4:-Microscopic observations bricks for $18 \%$

\section{Elongation of brick:}

The figure 5 shows respectively the results of the distortion of the bricks according to the latex content and the tensile strength of the brick.

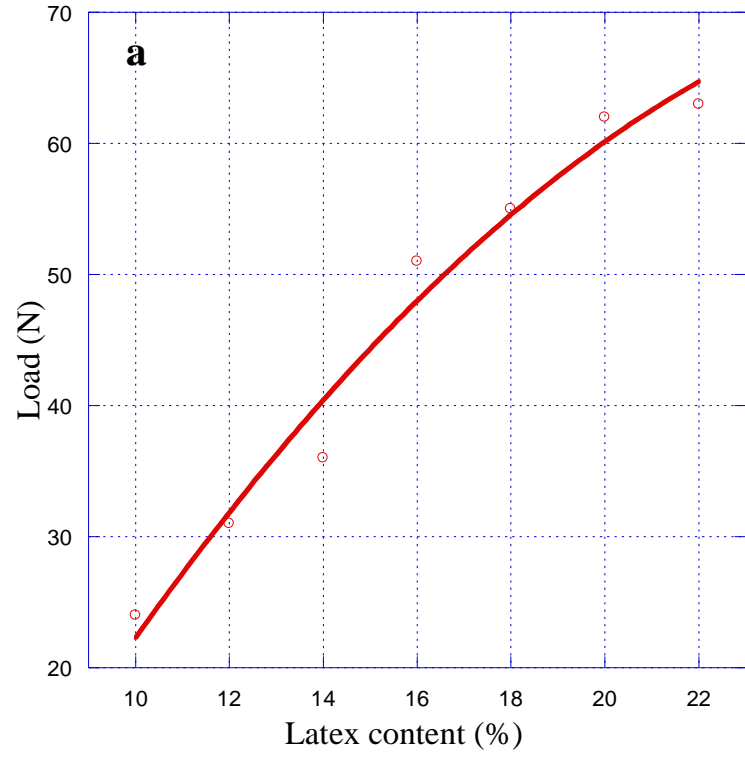

a) distortion depending on the latex content

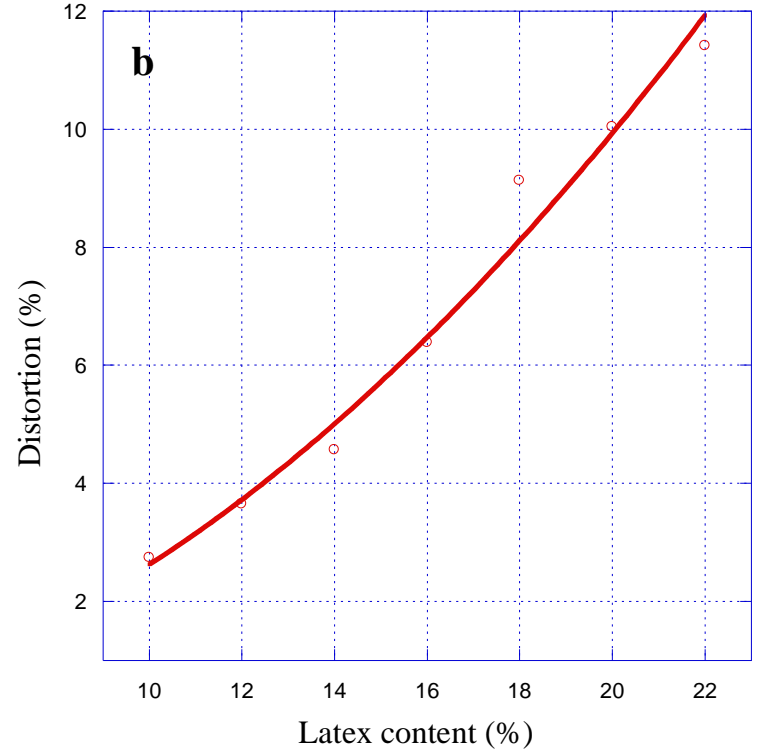

b) load as a function of the latex content

Figure 5:Behavior bricks on solicitation 
The elongation of the bricks and the force applied at break varies with the latex content: 10 to $22 \%$, distortion and breaking force of the brick increases. 12\% latex, for example, the tensile strength is $31 \mathrm{~N}$ and the distortion is $3.7 \%$ whereas $14 \%$ of latex the tensile strength is $40 \mathrm{~N}$ for a $5 \%$ strain. The latex affects the elongation of the bricks and their ability to resist. Indeed, the latex as natural rubber has elastic properties. However, the rate of elongation depends on the thickness of the applied rubber. The figure 6 shows Microscopic images of sections taken in the bricks containing 12 and $18 \%$ of latex. These images show that the thickness of the latex film between grains increases with the latex content. This explains the increase in elongation and tensile strength with the latex ratio. The latex thus gives bricks elasticity and resistance to stretching. The maximum strain is $12 \%$. The latex (rubber) is up to 750\% elasticity of ownership (CNUCED, 2013). Since the latex is mixed with the sand, this may explain the rate of elongation of $12 \%$ of bricks. This extension is due to the latex elastic property (rubber), and also depends on the thickness of the applied rubber.

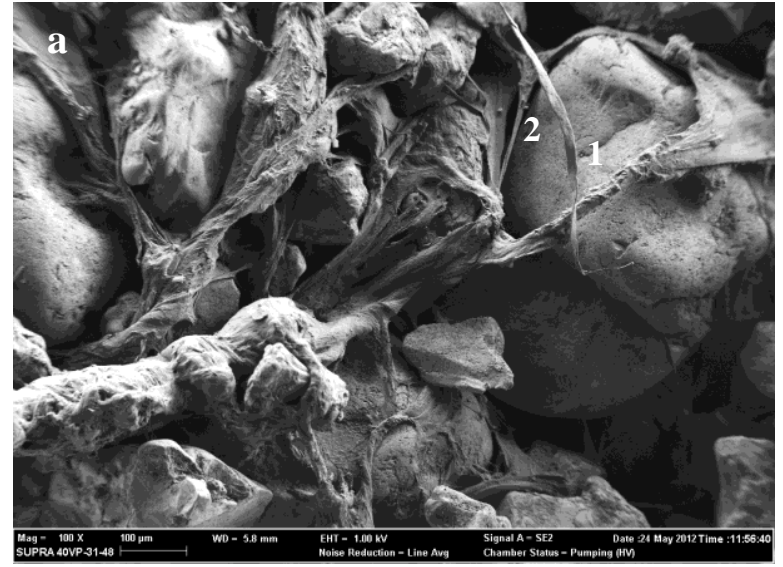

a ) Brick at $12 \%$ of latex;

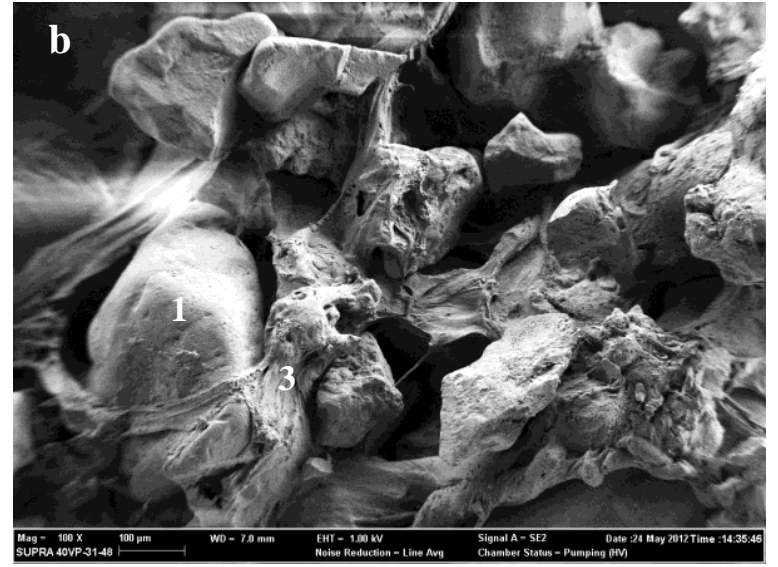

b) Brick at $18 \%$ of latex

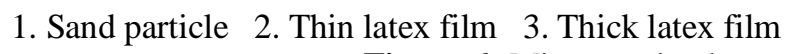

Figure 6 :Microscopic observation of a cross section of the bricks

\section{Usury resistance:}

The results obtained are represented in figure 7.

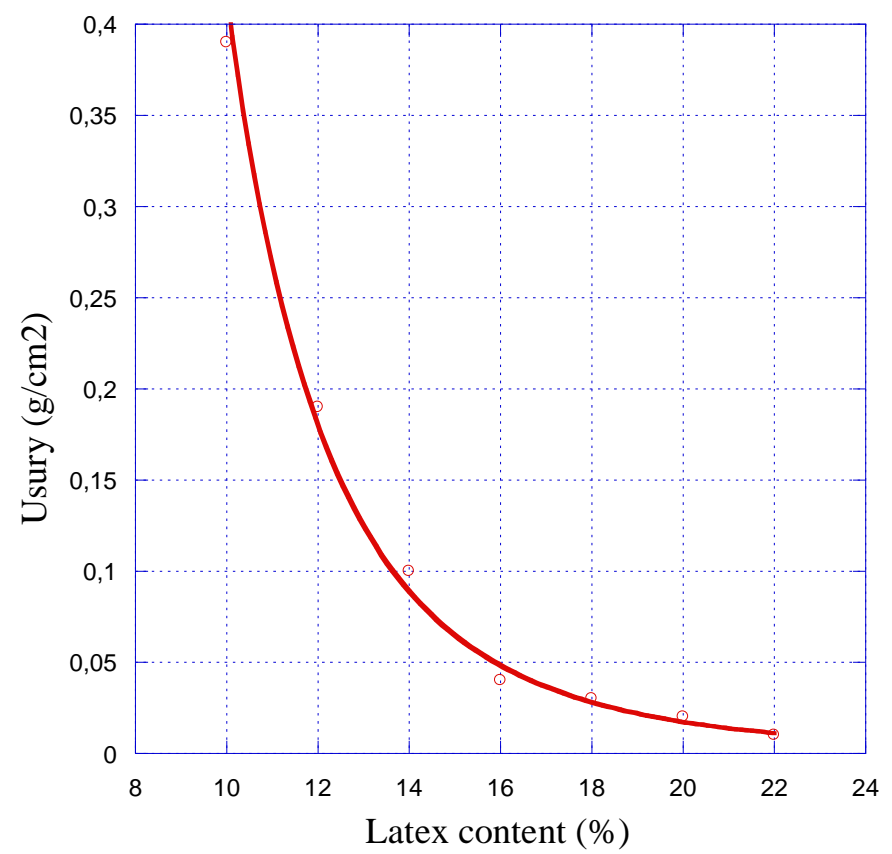

Figure 7:Resistance curve to wear according to the latex content 
The figure 7 shows the change in the wear of facing bricks according to the latex content. The wear decreases as latex content increases. The loss of weight by brushing therefore decreases with the increase of the latex content. 10 to $16 \%$, wear falls very rapidly and passes from 0.39 to $0.04 \mathrm{~g} / \mathrm{cm}^{2}$.

- 16 to $22 \%$, the change in the wear is low $(0.04 ; 0.01)$ and tends to stabilized $22 \%$. The sharp drop in wear between 10 and $16 \%$ can be explained by the fact that the amount of latex becomes sufficient to improve the cohesion between the particles of sand and latex. When the latex content increases (16 to 22\%), the material is more resistant to wear because the cohesion between the particles is very strong. So when brushing the loss of weight of the brick is very low.

Figure 8: shows the structure of the sand particles and the latex on the surface of bricks.
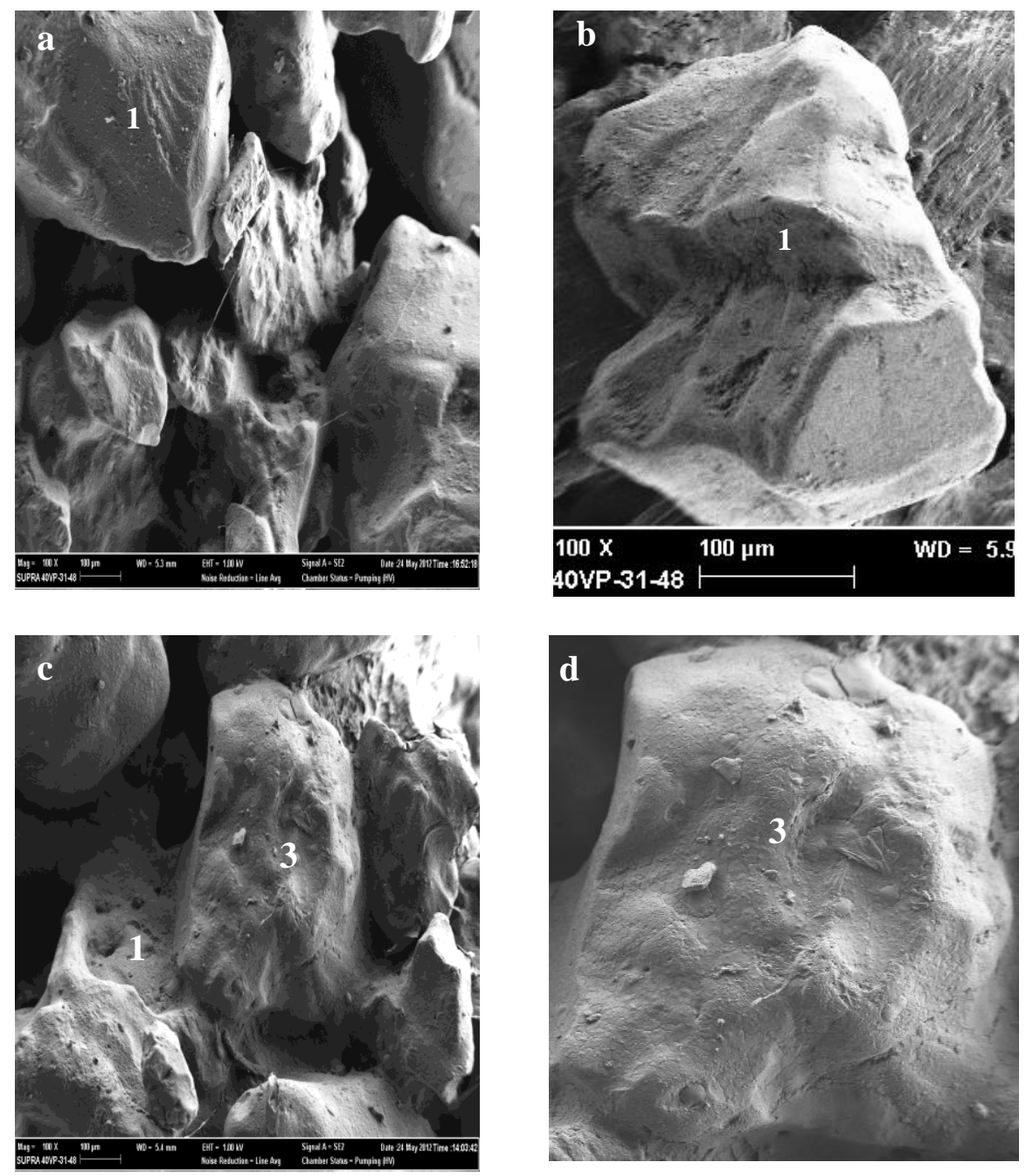
a) Brick (12\% of latex)
b) Uncoated particle of sand
c) Brick (18\% of latex) by latex

d) Particle of sand coated

\section{Sand particle 2. Latex 3. Particle of sand coated by latex}

Figure 8:- Structuring surface for bricks

By juxtaposition, these images allow the following remarks. For latex contents of $12 \%$ for example, the latex is essentially trapped in place between the sand particles. So there is not sufficient latex to coat the sand particles (figure 8-a). This explains the high bricks wear.

For latex contents of $18 \%$, the latex is found both between the sand grains on their surfaces. It is therefore sufficient to coat sand particles (figure 8-c). Bricks wear will be very low. Thanks to its properties the latex binder coat sand particles to form a coherent structure. The gradual formation of this structure which is the basis of the reduction of 
surface erosion. Latex incorporated into the sand has the effect of limiting surface erosion with a stabilizing wear at $0.01 \mathrm{~g} / \mathrm{cm}^{2}$. This limitation of surface erosion of clay bricks when the cement is incorporated therein (Kouakou, 2005). In Ivory Coast, the pressure exerted by atmospheric conditions on a surface produce a surface erosion of 2.5 $\mathrm{kg} / \mathrm{m}^{2}$ or $0.25 \mathrm{~g} / \mathrm{cm}^{2}$ (Assandé, 2007). There is a weight loss at wear lower than $0.25 \mathrm{~g} / \mathrm{cm}^{2}$. And $12 \%$ of latex is the minimum latex content from which the flexible bricks can be used in construction without having their surfaces protected. For high mechanical stress, bricks must be made with latex content up to $16 \%$.

\section{Conclusion:}

Various tests on bricks were used to determine the optimum latex content for having bricks with good mechanical characteristics. The study of the mechanical behavior of stabilized bricks made of hevea latex shows that they are influenced by latex content. This study also shows that for stabilized bricks with improved mechanical resistance, latex contents must be from 16 to $18 \%$. From $16 \%$ of latex, the bricks can be used in construction. We suggest $18 \%$ of latex content as possible to have bricks of best qualities.

\section{Bibliographicsreference:}

1. Assandé A. A. (2007).Valorisation des latérites de Côte d'Ivoire. Fabrication de briquettes de parement à base de latérite stabilisée à froid à l'aide d'un liant hydraulique : le ciment portland.Thèse de Doctorat, Université de Cocody, Abidjan; Côte d'Ivoire, $142 \mathrm{p}$.

2. Chrestin H. (1984). Le compartiment vacuo-lysosomal (les lutoïdes) du latex d'Hévéa brasiliensis: son rôle dans le maintien de l'homeostasie et dans le processus de senescence des cellules laticiferes. Thèse de Docteurès Sciences naturelles, France, $490 \mathrm{p}$.

3. CNUCED, (2013). Propriétés du caoutchouc naturel, Disponible auprès de http://www.unctad.info/fr/Infocomm/Produits-Agricoles/Caoutchouc/Description/Proprietes-du-caoutchoucnaturel/ . Consulté en 2013.

4. Jolissaint O. S. P. (2015). Conception de briquettes de façade flexibles pour les murs arrondis. Thèse de Doctorat des Sciences de la Terre. Option Géomatériaux, Université de Cocody, Abidjan, 132 p.

5. Kouakou C. H. (2005). Valorisation des argiles de Côte d'Ivoire : étude de la stabilisation à froid de l'argile de Dabou avec un liant hydraulique (le ciment Portland). Thèse de Doctorat des Sciences de la Terre, option Géomatériaux, Université de Cocody, Abidjan, 196 p. 